\title{
New Integration Prospects for the Metropolitan Area of the Strait: the Role of the Cities of Messina and Reggio Calabria in the Enhancement of Local Resources $\left.{ }^{*}\right]$
}

\author{
Alessandra Barresi ${ }^{1, a}$, Gabriella Pultrone ${ }^{1, b}$ \\ ${ }^{1}$ Università Mediterranea di Reggio Calabria-dArTe, via Melissari, 89124 Reggio Calabria, Italy \\ aalessandra.barresi@unirc.it, bgabriella.pultrone@unirc.it
}

Keywords: Availability and Activation of Local Resources, Build-up of Skills, Local Competitiveness, Metropolitan Area of the Strait, Natural and Cultural Heritage, Urban Performance, 2014-2020 EU Programming Period.

\begin{abstract}
This paper illustrates a hypothesis of research on the role of the two metropolitan cities of Messina and Reggio Calabria in the development of the Integrated Strait Area and on the one they may play in the broader Euro-Mediterranean context, in the light of the 2014-2020 EU programming period. In particular, the research refers to the enhancement and activation of local resources and is inspired by the study "La Nuova Occasione. Città e valorizzazione delle risorse locali", coordinated by Paola Casavola and Carlo Trigilia on behalf of Fondazione Res, whose method it shares and applies to the Strait Area, though with certain diversities due to the specific case concerned. The basic assumption is to believe that, today, the development and growth of territories depend on the functioning of cities, since they are the place where present and future residential areas, the idea of a government of public interest, intellectual activity and business management concentrate. Therefore, such cities should seize the chance to turn into catalysts of the economy, places of connectivity, creativity and innovation. This idea is even more rooted in the conurbation of the Strait of Messina, whose only possibility of future development, within a European geographical space characterized by the prevalence of strong and consolidated urban regions, may only derive from the capability of the two cities to become aware of their role in enhancing their particular local conditions and the varied latent potentials related to their specific local identity [1].
\end{abstract}

\section{The metropolitan dimension: a creative laboratory to experiment with innovation}

Since 2008, over a half of the world population has been living in urban areas. As a consequence, such areas are now the focus of international attention owing to their two-sided nature as places where, on the one hand, great opportunities of cultural, social and economic development converge and, on the other hand, great modern challenges worsen (poverty, discrimination, unemployment, crime, energy and environmental problems). Moreover, technology alone, without an authentic culture of innovation as a tool to develop effective policies and a widely shared vision of development, cannot resolve such challenges.

In particular, the above-mentioned areas play a crucial role in the sustainable development of the EU, as fertile ground where the Europe 2020 strategy goals can be variously achieved through an integrated approach that can direct the future of these new catalysts of the economy, places of connectivity, creativity and innovation, and services centres for their territories, in a wider global dimension of material and immaterial flows [2,3]. Nevertheless, the great challenges ahead will impact the European regions in various ways and to different extents, as it emerges from several EU documents, such as Regions 2020, which gives a first overview of the possible disparities they will cause and of their consequences on the future conception and investment priorities of the cohesion policy [4].

If the goal of economic, social and territorial cohesion has a strong urban dimension, then cities cannot be conceived any longer within their traditional administrative boundaries insomuch that the European Urban Agenda takes into account the interdependence between cities and surrounding areas 
by actively involving all urban dimensions, from minor centres to large metropolitan areas, in projects of inclusive, sustainable and smart growth [5].

Thus, the future revolves around cities, from the major to the minor ones, to those which are part of networks or metropolitan systems, whose functioning affects the competitiveness of regions and wider territories favouring EU integration and cohesion [6].

Considering the ongoing dynamics, in which municipal administrative boundaries do not correspond any longer to the physical, social, economic, cultural and environmental reality, it is fundamental to identify development pathways, which can be actually implemented in accordance with the strategic lines of the EU cohesion policies, as well as to elaborate innovative models of governance [7]. Such policies should be promoted at a global level and then adapted and calibrated to the different territories through suitable strategies and tools of enhancement and activation of local resources, i.e. of the so-called genius loci. In fact, the knowledge economy reasserts the central role of the territory in the production of wealth and advantages that are competitive because they are sustainable owing to their peculiar and unique nature, in a continuous dialectic between identity and more effective forms of innovation fed by creativity. Then, creativity becomes the indispensable quality of a city which is able to find the right integration between available local resource planning, interaction between stakeholders and growth of business activity $[8,9,10]$.

Cities are the protagonists of the EU approach to the incentives for growth and well-being also in the new 2014-2020 programming period. As a matter of fact, structural policies follow a "place-based" approach and aim at enhancing integrated territorial investments (ITI) and funding CLLD (Community Led Local Development) projects. In particular, the latter are a tool that has been regulated to pursue integrated local development on a sub-regional scale, with the primary contribution of local actors, which form a mixed partnership (public-private) and entrust the Local Action Group with an operational role (of management and administration). Within the EU Framework Programme for Research and Innovation Horizon 2020. Excellent Science Competitive Industries Better Society [11], the Tackling Societal Challenges pillar makes funds available to help cities face the main challenges they share at a European level, such as climate change, development of sustainable transport and mobility systems, availability of cheaper energy sources, capacity to ensure food quality and security and issues related to the ageing population [12]. In short, metropolitan areas will tend to increasingly become key actors in the European context as laboratories where it will be possible to experiment with more sustainable development as well as tools to boost the citizens' participation and political sharing. This is what emerges from initiatives like METREX, The Network of European Metropolitan Regions and Areas, founded in Glasgow in 1996, on the occasion of the Conference of Metropolitan Regions. It is a platform involving members from 50 of the 127 European metropolitan regions or areas to exchange knowledge, skills and experiences on metropolitan affairs and joint actions on themes of common interest [13].

With regards to Italy, Cittalia Report on the metropolitan cities shows that the territorial scale of these new administrative entities is the most suitable to face the most significant challenges of economy and of the Italian society. Furthermore, the full operation of the 14 cities identified by law, among which Messina and Reggio Calabria, would favour the achievement of more effective governance systems to reduce the gap between the centre and peripheries and better redistribute wealth and opportunities on the territory. Thanks to the new institutional subject, big Italian cities will have modes of governance similar to those of the big European centres but adapted to the peculiarities of the territories concerned [14].

Studies, reflections and institutional documents on urban issues highlight that Italy shares the EU approach since it puts such topics at the heart of its Urban Agenda and, above all, recognizes the importance of the metropolitan cities. In particular, the strategies, priorities and modes of use of the European structural funds for the 2014-2020 programming period - illustrated in the version of the Partnership Agreement for the new 2014-2020 Programming period of the Structural Funds, presented on 10 December 2013 - include a National Operational Programme on the metropolitan cities [15]. 
Each city of the south of Italy will be allocated from 80 to 100 million Euros, while those in the centre and in the north of the country and Sardinia will be allocated from 35 to 40 million Euros. The most important partners for the definition of the project contents will be the mayors of the capital municipalities (Urban authority). They will be also entrusted with the creation of partnerships and intercommunal projects, since the territory concerned will not be strictly limited to the political and administrative boundaries of the Metropolitan City, but it will extend to other territories based on functional interdependence.

Therefore, the two cities of the Strait, which have difficulty in defining their metropolitan dimension, will go through a new favourable period, which is also fostered by the "NOSTRA Network of Straits" Project, supported by the European Straits Network [16].

The project was approved within the EU Interregional Cooperation Programme INTERREG IV C and involves nine European partners (Strait of Dover; Strait of Messina; Strait of Kvarken; the Strait of Sicily; the Strait of Otranto; Romania; Gulf of Finland; Strait of Fehmarn Belt; Strait of Bonifacio). The territories overlooking these particular geographical areas share numerous problems (transport, economic development, maritime security), which have a considerable impact on the natural heritage [17]. To cooperate and share experiences may allow better identifying effective solutions to common problems and implementing more effective and eco-friendly policies. It is a golden opportunity for Messina and Reggio Calabria, since only a shared strategic vision may allow them to enhance their geographical position between Europe and the Mediterranean, to achieve a critical mass in order to enhance their numerous resources, which are mostly underused, and to start processes of sustainable development. In that way, they would become a single competitive "urban region" able to bridge the gap with the other historically stronger European areas.

\section{The Metropolitan Area of the Strait towards new scenarios of territorial competitiveness: guidelines for research}

The capacity to trigger territorial development depends on an intelligent and responsible use of resources. The concreteness of this conviction is proved by the acknowledgement of the transformation of markets and technologies which has led to the search for flexibility and quality in the production of less and less standardized goods and services [18]. In this respect, today, only cities can offer varied opportunities, such as vocational training, universities and research centres, infrastructure, qualified social and cultural services.

Contrary to what may be imagined, the role of the cities as driving force for local development is also compatible with the growing phenomenon of the globalization of productive processes. In general, according to a competitive strategy adopted to combat cost competition, relocation mainly concerns the simplest activities, while the search for innovation and quality leads to a greater territorial concentration. Moreover, globalization determines larger middle classes and the formation of well-educated, higher-income social groups that will considerably contribute to fuelling the demand for quality consumption, besides increasing tourist demand for the fruition of the cultural and natural heritage of the "historic" cities.

This basic assumption is even more rooted in the conurbation of the Strait of Messina. For Messina and Reggio Calabria, the two metropolitan cities overlooking the Strait, the possibility of future development, within the European geographical space, characterized by the prevalence of strong and consolidated urban regions, can only derive from their capability to become aware of their role in enhancing their particular local conditions (they belong to an area that can enjoy EU privileges because it is a cross-border region and is part of one of the European Straits) and the varied latent potentials related to their specific local identity. In other words, as Moraci writes, the future development of the two cities will depend on their capacity to replace the local conservative cultural élite with the leadership of the creative city. Referring to the Metropolitan Area of the Strait, Moraci also states that without any existing economic factor of metropolization, opportunity and 
geographical location play a start-up role if they are combined with governance capacity, with the strategy to adopt and with the local resources to use [19].

I order to illustrate the method to follow, it is crucial to start from the definition of local resources as that wealth of cultural and environmental assets, of scientific knowledge, of widespread know-how, rooted in production specializations that contribute to defining the identity of a place [18].

Over the years, the capacity of the cities to cherish and enhance these resources has influenced the local economic and social development, though with different modes and intensity. Therefore, the goal of the research activity is to recognize the driving role of the two metropolitan cities of the Strait in enhancing local resources. Furthermore, above all in the south of Italy, where the manufacturing industry is characterized by changeable productivity, such resources are the real assets for future scenarios of development and are perfectly consistent with the guidelines of the new EU programming period (Horizon 2020). In fact, today, in spite of a fragile manufacturing industry, local resources, which are the most significant part of the identity heritage of the south of Italy, represent considerable potentials for growth.

Consequently, cities should take the dual role of effective transformers of underused latent local resources and of generators of new resources that may integrate the existing ones also favouring their enhancement.

In order to show the role the cities of Messina and Reggio Calabria play, their level of performance will be analyzed with reference to their specific potential, which derives from the available local resources. This will allow checking how and to what extent they have been activated to pursue development.

The research activity aims at achieving its goal through a method consisting in three steps: identification of the quality and quantity of local resources and of their level of activation in the two metropolitan cities, which will imply the use of indicators different from those traditionally employed for city rankings; determination of what and how many factors influence the activation or non-activation of such resources; definition of the guidelines to follow, with a view to improving the potential yield of local resources in their socio-economic context.

The types of local resources considered within the research are: cultural and natural assets; scientific heritage from universities and research centres; build-up of skills acquired in long-term activities carried out in local communities. Today, these three groups of resources, which are often found together in cities and in their surrounding areas, have a particularly important function since, in combining identity, tradition and innovation, they give cities a solid competitive basis in the current organization of the economy. Though perfectly complementing each other, the groups of resources have different origins and peculiarities: cultural and natural heritage is linked to the history and natural characteristics of the territory; scientific knowledge derives from political choices that have led to the establishment of universities and research centres; the build-up of skills is the result of local capacities that have consolidated in time by interacting with the market.

The operational goal of the study is to analyze in detail two aspects of the identified local resources. A quantitative analysis aims at obtaining comparable measurements of the local resources and of their level of activation in different cities. To that purpose, specific indicators were set for the three types of local resources. A qualitative analysis aims at identifying the factors that influence the capacity of the cities to activate and enhance their resources. It is carried out by comparing the two cities of Reggio Calabria and Messina to other cities that are similar under certain specific conditions.

Thus, the first part of the research activity focuses on the construction of indicators of the quantity of local resources and of their level of activation, based on a common pattern that involves a direct measurement of the resources and an approximate calculation of the yields which may result from their activation. In the latter case, a comparison with the best performances of similar cities is required.

The second part of the study focuses on the activation processes and on the identification of the factors that may curb or boost the enhancement of local resources. It is also based on the comparison of similar cases with a view to understanding what factors influence the activation of local resources. 
There exist various types of factors: accidental or intentional, coming from the outside or from the inside, from public or private actors, from isolated initiatives or from more coordinated actions involving numerous actors.

The results of the first two parts of the research activity will allow evaluating the performances of the cities in each category of resources. Such an evaluation will concern the quantity and quality of resources as well as the absolute values observed for the activation of each type of resource. In addition, it will allow matching the theoretical values to the best activation for each type of resource. As a result, the level of activation should be calculated as the ratio between the values of the real activation and those of the best theoretical activation.

The last part of the research activity, which is aimed at providing guidelines to raise the level of potential yield of the cities, will be closely connected to the data from the two previous phases.

Finally, since the research method is based not only on absolute data concerning the quantity and activation of resources, but above all on relative data emerging from the comparison of similar cities, apart from Reggio Calabria and Messina, other urban contexts, which are strong urban or metropolitan elements within the European Straits, will be taken into account as reference parameters. This will enable to promote actions of integrated enhancement that can further the economic development of these particular geographical areas by exploiting to the full their specific potentials. With this respect, reference will be made to some of the eight European Straits that have been part of the ESI (European Straits Initiative) network since 2009 [20].

\section{References}

[*] This paper is the result of a joint consideration the two authors made on an ongoing research activity. However, the two paragraphs were written separately as specified below: "The metropolitan dimension: a creative laboratory to experiment with innovation" (Gabriella Pultrone); "The Metropolitan of the Strait toward new scenarios of territorial competitiveness: guidelines for research" (Alessandra Barresi).

[1] While this paper was being written, the Sicilian Regional Assembly rejected the Draft Law providing for the establishment of the metropolitan city of Messina. Beyond any legal and institutional aspect, which is not dealt with in this paper, the role of the two cities is deemed crucial to enhance the Strait Area so that it can acquire strategic importance in the Euro-Mediterranean context as the heart of a wider territorial platform in the south of Italy.

[2] Information on http://ec.europa.eu/europe2020/index_en.htm/

[3] European Union-Regional Policy: Cities of tomorrow. Challenges, vision, ways forward, European Union, October 2011

[4] Information on http://ec.europa.eu/regional_policy/sources/docoffic/working/regions2020/ index_en.htm/

[5] Issues paper for discussion in the forum "CITIES-Cities of Tomorrow: Investing in Europe", Brussels 17-18 $\quad$ February 2014, Information on http://ec.europa.eu/regional_policy/newsroom/detail.cfm?LAN=it\&id=1284\&lang=it/

[6] R. Camagni, S. Lombardi (Eds.): La città metropolitana: strategie per il governo e la pianificazione, Alinea, Firenze (1999)

[7] A. M. Colavitti: Governance del territorio. Beni Culturali. Piano urbanistico. Buone pratiche per la valorizzazione e la competitività, Alinea, Firenze (2013)

[8] A. Granelli: Città intelligenti? Per una via italiana alle Smart Cities, Luca Sossella Editore, Roma (2012)

[9] C. Landry: The creative city: a toolkit for urban innovators, Earthscan, London (2000) 
[10] R. Florida: Cities and the Creative Class, Routledge, New York (2004)

[11] European Commission: The EU Framework Programme for Research and Innovation. Horizon 2020. Excellent Science Competitive Industries Better Society. EU Research and Innovation: Tackling Societal Challenges, Information on http://ec.europa.eu/programmes/horizon2020/

[12] C. Pacente: La città metropolitana nell'UE. Programmazione comunitari, esperienze europee a confronto e nuove prospettive, Egea/Bocconi, Milano (2013)

Urban Audit and Eurostat, Information on http://www.eurometrex.org/ENT1/EN/About/about_METREX.php./

[14] Information on http://www.cittalia.it/index.php?option=com_k2\&view=item\&id=5048: citta-metropolitane-rapporto-cittalia-le-cifre-del-divario-tra-grandi-citta-e-cinture-urbane\&Itemi $\mathrm{d}=435 /$

[15] Information on http://capacitaistituzionale.formez.it/content/presentato-programmaoperativo-nazionale-citta-metropolitane/

[16] European Straits Initiative-ESI, Information on http://www.europeanstraits.eu/

[17] J. Gambino: Profili geopolitici dell'Area metropolitana dello Stretto, in: G. Tuccio (Ed.), Reggio Città metropolitana nell'area metropolitana dello Stretto, Iiriti, Reggio Calabria, (2013) pp. 297-323.

[18] P. Casavola, C. Trigilia: La nuova occasione. Città e valorizzazione delle risorse locali, Donzelli Editore, Roma (2012)

[19] F. Moraci: Costruire la città metropolitana di Reggio Calabria; fattori di metropolitanizzazione e creatività come dimensione strategica della politica urbana, in $\mathrm{G}$. Tuccio (Ed.), Reggio città metropolitana nell'area metropolitana dello Stretto, Iiriti editore, Reggio Calabria (2013)

[20] Provincia di Reggio Calabria-Commissione Tecnico-Scientifica Rete E.S.I. (European Straits Initiative): La Rete E.S.I. e i Fondi Strutturali 2014-2020: una strategia condivisa per lo sviluppo sostenibile dell'area dello stretto, Documento Preliminare, Reggio Calabria, giugno 2013 